Kodifikasia : Jurnal Penelitian Islam, Vol 15, No. 01 (2021), 37-53

DOI : 10.21154/kodifikasia.v15i1.2780

ISSN : 1907-6371 (Cetak)

ISSN : 2527-9254 (Online)

\title{
PERSEPSI GURU TENTANG ISLAM RAHMATAN LIL 'ALAMIN DAN DAMPAKNYA TERHADAP NASIONALISME PELAJAR
}

\author{
Susanto*
}

\begin{abstract}
ABSTRAK:
Guru merupakan salah satu faktor kunci dalam pembentukan pembentukan sikap pelajar. Corak pemahaman keislaman yang dimiliki guru, umumnya tidak hanya diekspresikan dalam praktik teologis, namun mempengaruhi sikap dirinya dalam berbangsa dan bernegara serta proses transmisi kepada pelajar. Tujuan penelitian dalam artikel ini adalah untuk mendeskripsikan persepsi guru di Jawa Barat terkait konsep Islam berwawasan rahmatan lil 'alamin serta dampak persepsi guru terhadap sikap nasionalisme pelajar di Provinsi Jawa Barat. Penelitian ini menggunakan metode penelitian kualitatif dengan teknik pengumpulan data melalui google form dan proses analisis data menggunakan analisis deskriptif. Responden guru dan pelajar berasal dari sekolah yang sama, berasal dari jenjang SMP dan SLTA di Jawa Barat. Penelitian terhadap persepsi guru terhadap konsepsi Islam berwawasan rahmatan lil alamiin dilihat dari 3 aspek yaitu persepsi terhadap konsep teologis, urgensi penerapan dan manfaat. Adapun sikap nasionalisme pelajar dilihat dari tujuh indikator meliputi; bangga sebagai bangsa Indonesia, cinta tanah air dan bangsa, menerima dan menghargai kemajemukan, bangga pada budaya yang beraneka ragam, menghargaai jasa para pahlawan dan mengutamakan kepentingan bangsa. Hasil penelitian ini ditemukan bahwa mayoritas guru memiliki pandangan positif terhadap konsepsi Islam berwawasan rahmatan lil alamiin dan berdampak terhadap sikap nasionalisme pelajar.
\end{abstract}

Kata Kunci: Persepsi; Islam Rahmatan Lil Alamiin; Nasionalisme.

\footnotetext{
* Pascasarjana Institut PTIQ Jakarta, email: susanto.kaisar@gmail.com
} 


\begin{abstract}
:
The teacher is one of the key factors in shaping student attitudes. The style of Islamic understanding that the teacher has is generally not only expressed in theological practice, but affects his attitude in the nation and state as well as the process of transmission to students. The research objective in this article is to describe the perceptions of teachers in West Java regarding the concept of Islam with the insight of rahmatan lil 'alamin and the impact of teacher perceptions on the nationalism attitude of students in West Java Province. This research uses qualitative research methods with data collection techniques through google form and the data analysis process uses descriptive analysis. Teacher and student respondents come from the same school, come from the junior and senior high school levels in West Java. Research on teachers' perceptions of the Islamic concept with rahmatan lil alamin insight is seen from 3 aspects, namely perceptions of theological concepts, urgency of application and benefits. As for the attitude of student nationalism, seen from seven indicators, they are; proud to be the nation of Indonesia, love the country and the nation, accept and appreciate diversity, be proud of diverse cultures, value the services of heroes and put the interests of the nation first. The results of this study found that the majority of teachers have a positive view of the concept of Islam with the insight of rahmatan lil alamin and have an impact on the nationalism of students.
\end{abstract}

Key word: Perception; Islam Rahmatan Lil 'Alamin; Nationalism.

\title{
PENDAHULUAN
}

Menurut Undang-undang No 20 Tahun 2003 Tentang Sistem Pendidikan Nasional, pendidikan nasional berfungsi mengembangkan kemampuan dan membentuk watak serta peradaban bangsa yang bermartabat dalam rangka mencerdaskan kehidupan bangsa, bertujuan untuk berkembangnya potensi pelajar agar menjadi manusia yang beriman dan bertakwa kepada Tuhan Yang Maha Esa, berakhlak mulia, sehat, berilmu, cakap, kreatif, mandiri, dan menjadi warga negara yang demokratis serta bertanggung jawab.

Di sisi lain, menurut Undang-undang Nomor 14 Tahun 2005 tentang Guru dan Dosen, Pasal 6 dinyatakan bahwa kedudukan guru dan dosen sebagai tenaga profesional bertujuan untuk melaksanakan sistem pendidikan nasional dan mewujudkan tujuan pendidikan nasional, yaitu berkembangnya potensi pelajar agar menjadi manusia yang beriman dan 
bertakwa kepada Tuhan Yang Maha Esa, berakhlak mulia, sehat, berilmu, cakap, kreatif, mandiri, serta menjadi warga negara yang demokratis dan bertanggung jawab.

Komitmen regulatif tersebut konsekuensinya perlu dukungan satuan pendidikan termasuk guru yang kompeten agar kualitas proses pembelajaran di sekolah sejalan dengan tujuan pendidikan nasional. Apalagi seiring dengan munculnya sejumlah kejadian kekerasan dan teror yang dipandang sebagai ekspresi kesalehan dalam beragama, kompetensi guru dalam memahami ajaran agama termasuk Islam sangat diperlukan agar transfer pengetahuan kepada pelajar senafas dengan hakikat ajaran Islam.

Islam sebagai agama rahmat untuk semua merupakan agama yang telah diwahyukan oleh Allah SWT untuk kebaikan semesta alam dengan proses pewahyuan secara bertahap melalui para Nabi dan Rasul-Nya. Pentahapan proses pewahyuan tersebut selain mempertimbangkan aspek psiko-sosial penerima ajaran agama juga untuk mengindari penolakan yang rentan menimbulkan gejolak sosial masyarakat. Dengan demikian, pendekatan harmoni dalam proses perbaikan sistem sosial telah tersirat dalam ajaran Islam sebagai rahmat untuk semua.

Islam berasal dari kata salima, yang artinya menyerah, tunduk dan patuh. Menyerah, tunduk dan patuh kepada Tuhan yang menciptakan semua yang ada dalam kehidupan ini, bukan meyerah, tunduk dan patuh kepada hawa nafsu, serta kepentingan-kepentingan materi. Hanya patuh dan tunduk kepada Allah SWT yang akan membawa keselamatan dan kedamaian. ${ }^{1}$

Salah satu ciri agama Islam adalah perdamaian, sesuai makna Islam itu sendiri. Islam datang tidak hanya memperkenalkan eksistensinya sebagai agama, namun juga mengakui eksistensi agama-agama lain, sehingga umat Islam diperintahkan menghormati pemeluk agama lain dan tidak memaksakan dalam berdakwah, walaupun Allah SWT sebenarnya denga kekuasaan-Nya dapat menjadikan satu umat.

Eksistensi Islam sebagai agama dimaksud merupakan perwujudan rahmatan lil 'alamin. Jika ditelusuri dan dikaji lebih jauh, cerminan rahmat dalam Islam, tersurat dan tersirat dalam beberapa hal; pertama, hakikat ajaran Islam sebagaimana termaktub dalam teks-teks ayat al-Qur'an dan Hadits; kedua, ketauladanan Rasulullah Muhammad SAW, baik dalam kehidupan agama, bermasyarakat dan bernegara; ketiga, pandangan sahabat dan ulama yang ramah serta sesuai konteks zamannya.

Keagungan Islam sebagai agama yang menerapkan konsep rahmatan lil alamiin, sejatinya juga tercermin dalam upaya mengkoreksi nilai dan sistem

\footnotetext{
${ }^{1}$ Musa Asy'arie, Filsafat Islam Tentang Kebudayaan (Yogyakarta: LEFSI, 1999), 55.
} 
yang berlaku sebelum kehadiran Islam dengan pendekatan yang humanis dan tanpa konfrontatif. Tahapan ke tahapan terus dilakukan tanpa henti dalam meluruskan kesalahan ajaran jahiliyah dengan tetap mengakomodasi nilai lokal masyarakat tempat Islam diwahyukan sepanjang tidak bertentangan secara prinsip dengan unsur pokok ajaran Islam. ${ }^{2}$

Meski cerminan ajaran Islam demikian, tidak sedikit praktik keberagamaan di masyarakat justru tidak mencerminkan sebagai manusia yang beragama. Praktik kekerasan, terorisme, konflik atas golongan yang mengatas namakan agama, sejatinya bertolak belakang dengan etika beragama dan ajaran Islam yang paling pokok.

Beragam pemikir muslim, baik Indonesia maupun mancanegara, kehadiran Nabi Muhammad SAW bukan semata sebagai rahmat untuk pemeluk agama Islam tetapi rahmat untuk semua manusia beserta semesta alam. Konsepsi Islam seperti ini secara inheren menolak anggapan sebagian masyarakat barat dalam mengenal Islam. Islam disamakan dengan fanatisme, sebagaimana disebut dalam karya Voltaire, Mahomet, of fanatism, kekuasaan politik Islam disamakan dengan kezaliman, Islam disamakan dengan primitif dan lain sebagainya. ${ }^{3}$

Pendek kata, berdasarkan uraian tersebut di atas dapat dipahami bahwa Islam sebagai agama rahmatan lil alamiin adalah agama yang mengajarkan nilai-nilai kebaikan, kasih sayang, kedamaian dalam kehidupan manusia dan seluruh alam.

Meski Islam dilihat dari perspektif hakikat ajaran, sebagai rahmat, namun dalam konteks penyelenggaran pendidikan, konsepsi tersebut perlu difahami oleh guru, agar nilai-nilai kerahmatan dalam Islam dapat diterapkan dalam kehidupan agama, bermasyarakat berbangsa dan bernegara. Mengingat guru merupakan pilar penting dalam transmisi pengetahun dan pembentukan sikap pelajar, maka persepsi yang melekat pada guru tentang keislaman, secara perlahan akan berpengaruh terhadap cara berfikir dan cara memandang Islam dan cara pandang kebangsaan yang ada pada pelajar.

Dengan demikian, penelitian terhadap persepsi guru terkait konsepsi Islam rahmatan lil 'alamin dan dampaknya terhadap sikap nasionalisme pelajar perlu dilakukan. Hal ini dikarenakan; pertama, banyak studi melaporkan, persepsi keagamaan seseorang tampaknya berelasi dengan konsepsi berbangsa dan bernegara yang dimiliki; kedua, persepsi yang dimiliki guru, baik langsung maupun tidak langsung juga akan mempengaruhi terhadap persepsi dan sikap pelajar; ketiga, kualitas nasionalisme pelajar, faktor

${ }^{2}$ Jamaludin, Islam Dan Masa Depan Covil Society (Depok: Mutiara Press, 2019), 21.

${ }^{3}$ Charles Kurzman, Islam Liberal (Jakarta: Paramadina, 2003), xi.

Kodifikasia: Jurnal Penelitian Islam, Volume, 15 No. 1 Tahun 2021 
pembentuk yang cukup dominan berasal dari proses transmisi pendidikan di sekolah.

Telah banyak tema penelitian terkait Islam berwawasan rahmatan lil 'alamin yang dilakukan sejumlah peneliti di Indonesia. Fokus penelitian yang ada umumnya terkait edukasi konsep Islam rahmatan lil 'alamin kepada masyarakat luas, ${ }^{4}$ telaah kopsep, ${ }^{5}$ pelembagaan dalam manajemen satuan pendidikan Islam ${ }^{6}$ serta kendala dan tantangan penerapan.

Dalam penelitian ini penulis akan mendeskripsikan persepsi guru tentang konsep Islam berwawasan rahmatan lil 'alamin dan dampaknya terhadap sikap nasionalisme pelajar di sekolah umum di Jawa Barat. Kebaruan penelitian ini terletak pada upaya mendalami dampak persepsi guru tentang konsep Islam rahmatan lil 'alamin terhadap jiwa nasionalisme pelajar, mengingat religiusitas dan nasionalisme merupakan pilar karakter yang fundamental dan merupakan mandat tujuan pendidikan nasional.

Pemilihan lokasi penelitian tersebut didasarkan pertimbangan; pertama, Jawa Barat merupakan salah satu wilayah yang memiliki kerentanan munculnya radikalisme, mengingat sejumlah kasus teror terjadi dan hasil pendalaman aparat diantaranya ada terduga pelaku tinggal di Jawa Barat. Kedua, Jawa Barat memiliki sekolah umum cukup banyak, jumlah SMA Negeri 501 dan 114 swasta, sementara banyak ahli menyatakan bahwa dibandingkan sekolah berbasis agama, sekolah umum lebih rentan memiliki pemahaman keagamaaan yang ekstrim ${ }^{7}$ Ketiga, nasionalisme pelajar merupakan kebutuhan mutlak untuk mengukur keberhasilan pendidikan karakter.

Tujuan penelitian dalam artikel ini adalah untuk mendeskripsikan; pertama, persepsi guru di Jawa Barat terkait konsep Islam berwawasan rahmatan lil 'alamin; kedua, dampak persepsi guru terkait konsep Islam berwawasan rahmatan lil 'alamin terhadap sikap nasionalisme pelajar di Jawa Barat. Hasil penelitian ini diharapkan dapat bermanfaat secara teoritis dan praktis. Secara teoritis diharapkan dapat memberikan sumbangsih ilmiah untuk pengembangan sistem layanan pendidikan. Secara praktis dapat menjadi pijakan untuk penguatan kompetensi guru terkait wawasan keislaman dan penguatan sikap nasionalisme pelajar.

${ }^{4}$ Arina Rahmatika and Ninda Khoirullina, "Upaya Meneguhkan Islam Rahmatan Lil'alamin Melalui Majalah Bangkit," Jurnal Dakwah Dan Komunikasi IAIN 5, no. 2 (2020).

${ }^{5}$ Maufur, "Islam Sebagai Rahmatan Lil-'Alamin," Kawistara 2, no. 1 (2012): 97-100.

${ }^{6}$ Hadi Purnomo and Umiarso Umiarso, "Pengelolaan Dan Sistem Pendidikan Islam Berwawasan Rahmatan Lil 'Alamin: Kajian Atas Gerakan Pendidikan Fethullah Gulen Movement," Cendekia: Jurnal Kependidikan Dan Kemasyarakatan 16, no. 2 (November 22, 2018): 223, https://doi.org/10.21154/cendekia.v16i2.1288.

${ }^{7}$ Dinas Pendidikan Jawa Barat, 2019. 
Jenis penelitian ini merupakan penelitian kualitatif. Menurut Bogdan dan Taylor, penelitian kualitatif adalah penelitian yang menghasilkan data deskriptif yang berupa kata-kata tertulis atau lisan dari subyek manusia dan perilaku yang dapat diamati. ${ }^{8}$ Sementara menurut Sugiyono, penelitian kualitatif adalah metode penelitian yang berlandaskan pada filsafat pospositivisme, digunakan untuk meneliti kondisi obyek alamiah, peneliti sebagai instrumen kunci. ${ }^{9}$ Dengan demikian, peneliti dalam hal ini akan menyajikan data secara obyektif, natural sebagaimana data apa adanya bersumber dari lapangan penelitian.

Penelitian ini dilakukan di Jawa Barat, sejak Mei - Juni 2020. Subyek yang menjadi responden dalam penelitian adalah guru dan pelajar tingkat SMP dan SLTA di Kota Depok, Kota Bogor dan Kabupaten Bogor Jawa Barat. Teknik pengumpulan data dalam penelitian ini menggunakan google form kepada responden 250 guru berasal dari Kota Depok, Kota Bogor dan Kabupaten Bogor, serta pelajar di sekolah yang sama dengan guru, dengan jumlah total responden pelajar jenjang SMP dan STLA berjumlah 625 responden. Analisis deskriptif digunakan oleh peneliti untuk menggambarkan persepsi dan sikap nasionalisme pelajar dalam penelitian ini.

\section{PEMBAHASAN}

\section{Persepsi}

Kata persepsi dalam bahasa Inggris dikenal "perception" berasal dari bahasa Latin perceptio, dari percipere diartikan menerima atau mengambil. ${ }^{10}$ Menurut Muhammad Miftah, persepsi diartikan sebagai tanggapan langsung terhadap suatu hal. Sementara menurut istilah, banyak ahli memberikan pandangan yang beragam mengenai persepsi. Menurut Prof Sitepu dalam Miftah, ${ }^{11}$ persepsi merupakan cara seseorang melihat, mamandang, memaknai sesuatu obyek. Obyek yang dimaksud dapat berupa obyek yang bersifat materiil maupun yang lainnya. Dari pandangan tersebut di atas dapat dipahami bahwa persepsi merupakan cara seseorang melihat sesuatu atau suatu obyek.

Menurut pandangan Muhammad Furqon ${ }^{12}$ sejatinya terdapat beragam penyebab utama yang dialami seseorang dalam membentuk persepsinya.

${ }^{8}$ Lexy J. Moleong, Metodologi Penelitian Kualitatif (Bandung: PT Remaja Rosdakarya, 2002), 9.

9 Sugiyono, Metode Penelitian Pendidikan (Pendekatan Kuantitatif, Kualitatif, Dan RED), Cet. 25 (Bandung: Alfabeta, 2017), 15.

${ }^{10}$ Alex Sobur, Psikologi Umum (Bandung: Pustaka Setia, 2003), 445.

${ }^{11}$ Muhammad Miftah, Komunikasi Pendidikan Yang Ramah Anak (Jakarta: Inisiasi Press, 2018), 19.

${ }^{12}$ Jamaludin, Kepemimpinan Pendidikan (Depok: Mutiara Press, 2020), 20.

Kodifikasia: Jurnal Penelitian Islam, Volume, 15 No. 1 Tahun 2021 
Fakttor tersebut dapat berupa; personal penerima, konteks, dan obyek yang dipersepsikan olah subyek.

Sementara Jamaludin ${ }^{13}$ menyatakan bahwa faktor-faktor dominan yang mempengaruhi seseorang dalam membentuk persepsi adalah pembentuk persepsi seseorang yaitu: pertama; faktor internal subyek yang mempersepsi; dalam hal ini termasuk kepribadian, sikap, karakter yang bersangkutan, interest, kondisi kejiwasan serta afiliasi; kedua, faktor pengalaman, dalam hal ini termasuk pengalaman yang telah dialami oleh subyek serta input pengetahuan dan pendidikan yang diterima; ketiga, kondisi lingkungan; dalam hal ini termasuk lingkungan keluarga, komunitas sosial, serta faktor eksternal lain yang dapat mempengaruhi persepsi terhadap subyek.

Sementara Alport dalam Jamaluddin ${ }^{14}$ berpendapat bahwa persepsi merupakan suatu proses kognitif yang di pengaruhi oleh pengalaman, cakrawala, dan pengetahuan individu. Proses kognitif dapat terjadi melalui proses belajar dengan guru, orangtua maupun lingkungan interaktifknya. Pada saat guru memiliki pandangan yang benar, obyektif dan utuh terkait cara memandang suatu obyek, maka pelajar perlahan akan terpandu terstimulasi pandangannya. Begitupula sebaliknya, jika guru memiliki pandangan yang salah terhadap suatu hal, rentan mempengaruhi proses pembentukan pandangan pelajar.

Guru mengemban peranan penting dalam pembentukan persepsi pelajar. Apalagi posisi guru dikenal al-mu'alim yang mendapat amanah memberikan ilmu dalam majllis taklim. Artinya guru adalah seseorang yang memberikan pengetahuan dan mengenalkan cara memandang suatu hal dengan cara yang tepat. Menurut Warson Ahmad, guru memegang misi utama sebagai pendidik profesional yang bertugas mendidik, membimbing, menfasilitasi, menstimulasi, mengembangkan seluruh potensi pelajar dengan berbagai latar belakangnya yang beragam serta mengevaluasi hasil belajar agar dapat tumbuh dan berkembang secara optimal. Pendek kata, guru memiliki peran yang fundamental dalam proses pembentukan persepsi pelajar terhadap suatu hal termasuk persepsi keagamaannya.

\section{Konsep Islam Berwawasan Rahmatan Lil Alamiin}

Konsepsi Islam berwawasan Rahmatan lil 'alamin merupakan konsep teologis yang syarat dengan pembumian nilai-nilai universalitas ajaran Islam, ramah, kasih sayang dan bagi seluruh semesta alam. Maka, kehadiran Islam rahmatan lil alamiin, mesti mencerminkan konteks masyarakat yang harmonis, demokratis, non diskriminasi, tanpa kekerasan, penuh kedamaian

\footnotetext{
${ }^{13}$ Jamaludin, 17.

${ }^{14}$ Jamaludin, Islam Dan Masa Depan Covil Society, 120.
}

Kodifikasia: Jurnal Penelitian Islam, Volume, 15 No. 1 Tahun 2021 
dan menjunjung tinggi nilai-nilai kemanusiaan antar sesama meski latar belakang sosialnya berbeda serta merawat lingkungan alam semesta secara kolektif.

Kolektifitas antar individu dan kelompok masyarakat yang berbeda, menerapkan gotong royong sebagai bagian dari kearifan yang tumbuh di masyarakat, untuk kemajuan dan kebaikan masa depan bangsa, merupakan bagian dari nilai pokok konsepsi Islam Rahmatan Lil Alamiin. Sebaliknya, praktik diskriminasi terhadap minoritas agama, suku, golongan serta kelompok lainnya yang dilakukan oleh seseorang atau kelompok, apalagi mengatas namakan agama, hal tersebut jelas bukan cerminan Islam rahmatan lil alamiin, namun justru bertolak belakang dengan konsepsi dimaksud. ${ }^{15}$

Perspektif rahmatan lil alamiin dalam konsepsi keislaman, dapat dilihat dari berbagai sudut pandang disiplin ilmu lain. Inilah yang dikenal dengan tinjauan interdisipliner. Nilai kerahmatan dalam Islam tidak hanya dilihat dari sudut pandang teologis, namun juga didekati dari sudut pandang antropologi, sosiologi dan filsafat.

Secara historis, agama Islam telah hadir dengan konteks latar belakang sejarah sosial-budaya Arab yang khas. Sebagian nilai dna norma budaya Arab bertentangan dengan ajaran pokok Islam, namun sebagian nilai-nilai kulturalnya dapat beriringan dengan Islam. Maka, wajar jika ajaran Islam terkadang kritis terhadap budaya, namun pada saat yang sama akomodatif terhadap budaya lain sepanjang memenuhi unsur kemaslahatan menurut Islam. Akomodasi sebagian budaya Arab yang relevan dengan ajaran Islam merupakan bentuk kearifan ajaran, namun pada saat kritis bahkan meluruskan melalui norma baru yang bertentangan dengan nilai yang dianut sebelumnya, hal ini merupakan bentuk perbaikan sistem agar lebih manusiawi. Inilah kekuatan Islam sebagai agama sekaligus berorientasi peradaban.

Dari tinjauan antropologi, model akulturasi menurut Stephenson yaitu pertama, penyesuaian (asimilated). Hal ini dimaknai sebagai proses penyesuaian dan adaptasi suatu budaya terhadap budaya lain, kedua, perpaduan (Integrated) yaitu perpaduan 2 (dua) atau lebih kebudayaan secara seimbang dan cenderungnya adalah membentuk budaya baru, ketiga, peminggiran (marginalized) yaitu terpinggirnya suatu budaya oleh budaya lain yang lebih dominan, keempat, pemilahan (separated) yaitu pemilahan suatu bagian atau elemen tertentu dari suatu budaya dan diadopsi oleh budaya lain ${ }^{16}$

${ }^{15}$ Solehudin, Menuju Islam Ramah (Jakarta: El-Kahfi, 2009), 15.

${ }^{16}$ Jeni Messakh, "Wujud Akulturasi Sebagai Pembentuk Identitas Arsitektur Nusa Tenggara Timur," E-Journal Graduate Unpar 1, no. 2 (September 29, 2014): 178-88, https://journal.unpar.ac.id/index.php/unpargraduate/article/view/1196.

Kodifikasia: Jurnal Penelitian Islam, Volume, 15 No. 1 Tahun 2021 
Akomodasi Islam dengan nilai dan budaya yang berkembang di masyarakat merupakan tantangan sekaligus peluang. Tantangan karena memerlukan kapasitas pemeluknya untuk memaknai secara kreatif namun tetap proporsional dan kokoh dalam tauhid, agar tidak terpapar dengan pengaruh eksternal yang dapat membelokkan sikap keagamaannya untuk kepentingan meaterialistik, sesesaat dan jangka pendek. Di sisi lain, dapat menjadi peluang jika pemeluknya mampu beradaptasi dengan tetap teguh dengan keberislamannya. Hal tersebut telah banyak dicontohkan oleh Nabi Muhammad Saw, beliau dalam beragama pada saat tertentu akomodatif terhadap konteks budayanya yang membesarkan, namun tetap kritis dan meluruskan jika ada hal yang tidak sejalan dengan ajaran Islam.

Contoh kongkrit kritisisme terhadap budayanya sendiri tempat ia bertumbuh, yang dilakukan oleh Nabi Muhammad Saw adalah kritis dan menolak secara tegas terhadap budaya mengubur hidup-hidup anak perempuan di kalangan bangsa Arab sebelum Islam. Mengubur hiduphidup anak perempuan merupakan tradisi bangsa arab sebelum Islam yang telah turun temurun, bahkan melekat dalam budaya. Nabi menentang keras, bahkan Allah berfirman dalam surat At-Takwir yang artinya "Dan apabila bayi-bayi perempuan yang dikubur hidup-hidup ditanya, karena dosa apakah dia dibunuh." (Q.s. At-Takwir: 8-9).

Di sisi lain, akomodasi Nabi Muhammad SAW terhadap budaya lain yang berkembang di masyarakat, sebagai contoh; kebiasaan menerangi Masjid dengan lampu minyak. Menilik sejarah, hal tersebut berawal dari aspirasi Tamim Ad-Dari. Meski awalnya telah dipraktekkan di Gereja Kristen, namun dipandang maslahah sehingga Rasulullah mengizinkan Masjid menggunakannya sebagaimana juga dilakukan di Gereja.

Dilihat dari perspektif sejarah, Islam Rahmatan Lil Alamiin yang telah dipraktekkan Nabi Muhammad SAW tidak sekedar sebagai agama tetapi merupakan norma pokok untuk mereformasi bahkan merevolusi kebiasaan, budaya dan adat yang tidak berperikemanusiaan yang tumbuh dan berkembang di masyarakat arab tempat kehadiran Islam.

Islam sebagai rahmatan lil 'alamin, meniscayakan bahwa nilai Islam dikembangkan sebagai perekat, bukan justru medium pemecah dan konflik sosial. Dengan potret sosio-kultural masyarakat Indonesia yang beragam, multi agama, budaya, status ekonomi, struktur sosial, maka pembumian Islam rahmatan lil 'alamin, sangat diperlukan untuk membangun peradaban bangsa yang rukun, syarat dengan gotong royong, saling tenggangrasa, toleransi dan merawat kedamaian antar sesama dalam konteks kesatuan sebagai bangsa Indonesia. Hal tersebut semakin meneguhkan Islam itu sebagai agama demokratis, berperadapan dan senantiasa menjujung tinggi 
nilai-nilai kemanusiaan dalam jangkar pluralitas menuju Indonesia yang makmur dan sejahtera.

Dengan demikian, keragaman dapat dilihat sebagai kekayaan dan sekaligus kekuatan bangsa. Karena dengan keragaman agama, budaya, etnis, dan struktur sosial dapat menjadi modal sosial yang berharga bagi negara untuk membangun peradaban yang saling melengkapi, mengisi, memperkuat dan saling menguatkan satu dengan yang lainnya. Inilah kekayaan bangsa yang tak dapat tergantikan oleh apapun. Kosekuensinya, kemampuan manajemen konflik dalam mengelola perbedaan yang diperlukan agar keragaman tidak menjadi ancaman namun justru kekayaan. ${ }^{17}$

Agama, dalam kaitannya dengan masyarakat mempunyai dampak positif berupa daya penyatu (sentripental), dan dampak negatif berupa daya pemecah (sentrifugal). Agama yang mempunyai sistem kepecayaan dimulai dengan penciptaan pandangan dunia baru yang di dalamnya konsepsi lama dan pelembagaanya bisa kehilangan dasar adanya. Meskipun demikian suatu agama juga dapat besifat universal, namun hal tersebut ditujukan kepada sekelompok orang yang sedikit banyak homogen. Agama menjadi solidaritas kelompok baru yang tertentu. Perpecahan dalam suatu kelompok akan timbul jika terdapat penolakan terhadap pandangan hidup lama atau yang berbeda dengan agama. ${ }^{18}$

Kehidupan beragama tidak hanya ditandai oleh kehadiran berbagai agama yang secara eksistensa memiliki tradisi yang berbeda satu sama lain, akan tetapi juga ditandai oleh pluralitas internal masing-masing agama, baik berkenaan dengan aspek penafsiran maupun aspek pelembagaanya. Perlu digarisbawahi bahwa pluralitas agama berkaitan dengan masalah yang sangat peka. Sebab agama berkaitan dengan keyakinan tentang sesuatu yang absolute, suatu yang "ultimate", yang menyangkut keselamatan hidup manusia setelah "kematian".

Dilihat dari sudut pandang sosiologi, Islam sebagai agama rahmat meniscayakan fungsi integrasi sosial. Dalam pandangan Durkheim, agama berfungsi untuk integrasi dan stabilitas. ${ }^{19}$ Agama berfungsi untuk mengingat orang-orang dalam satu kesatuan yang sama. Segala perbedaan yang dimiliki pemeluknya dapat disatukan dengan agama. Dengan demikian, orang yang 2019).

${ }^{17}$ Ali Imron, Membangun Islam Nusantara (Jakarta: Pusat Kajian Islam Nusantara,

${ }^{18}$ M. Munandar Soelaeman, Ilmu Sosial Dasar Teori Dan Konsep Ilmu Sosial (Bandung: ERSCO, 1987), 229. 166.

${ }^{19}$ Doyle Paul Johnson, Teori Sosiologi Klasik Dan Modern (Jakarta: Gramedia, 1988), 
beragama memiliki solidaritas dan sikap yang menyatukan perbedaan bukan justru menjadikan konflik dan retak secara sosial. ${ }^{20}$

Sementara dilihat dari kajian filsafat, konsep Islam sebagai rahmat senafas dengan humanisme teosentris. Tokoh ternama Jaquet Maritain, membagi humanisme ke dalam dua kelompok yaitu humanisme teosentris, dan humanism antroposentris. ${ }^{21}$ Humanisme teosentris menjadikan Tuhan Sang Pencipta sebagai pusat manusia, karena Tuhan telah memberikan segala anugerah yang diterima oleh manusia. Sementara, konsep humanisme antroposentris menjadikan manusia sebagai pusat kekuatan.

Humanisme antroposentris dimaksud sejalan dengan pandangan Iqbal bahwa nilai-nilai humanisme dalam Islam yaitu kebebasan, persaudaraan dan persamaan. ${ }^{22}$ Secara prinsip, Islam sebagai agama rahmat memberikan jaminan dan perlindungan terhadap semua umat. Praktik kasih sayang yang dimandatkan oleh ajaran Islam tidak hanya kepada sesama pemeluk agama Islam, tetapi juga kepada pemeluk agama lain agar tetap saling menyayangi, menghormati dan menghargai.

Dengan demikian, dilihat dari berbagai sudut pandang, Islam sebagai agama rahmat meniscayakan pemikiran dan perilaku yang damai, toleran, saling menghargai, saling menghormati dan tidak melakukan tindakan yang merugikan orang lain, baik dalam lingkup seagama maupun agama lain.

\section{Persepsi Guru Tentang Konsep Islam Berwawasan Rahmatan Lil 'Alamin} Pandangan guru terhadap konsep keagamaan, apapun agamanya termasuk agama Islam akan mempengaruhi konsep religiusitas pelajar. Apalagi posisi guru tidak hanya berperan sebagai fasilitator, mobilitasor tetapi juga menjadi inspirator dan teladan untuk pelajar. Konsekuensinya pandangan keislaman yang dimiliki guru, sangat menentukan.

Survey berbasis virtual terhadap 250 guru Sekolah Umum jenjang SMP dan SLTA di Jawa Barat ditemukan bahwa persepsi guru terhadap Konsep Islam berwawasan Rahmatan Lil 'Alamin dilihat dari 3 aspek meliputi persepsi terhadap konsep teologis, urgensi penerapan dan manfaat. Gambaran pandangan guru di Jawa Barat sebagai berikut:

\footnotetext{
${ }^{20}$ Firman Manaf, Agama Dan Integrasi Sosial (Jakarta: Wacana Press, 2018), 123.

${ }^{21}$ Jaquet Maritain, Integral Humanism: Temporal And Spiritual Problem of a New Christen Don (USA: University of Rorte Dome, 1973), 37.

${ }^{22}$ Muhammad Iqbal, The Reconstruction of Religious Thought in Islam (Lahore: Asyraf Publication, 1971), 154.
} 


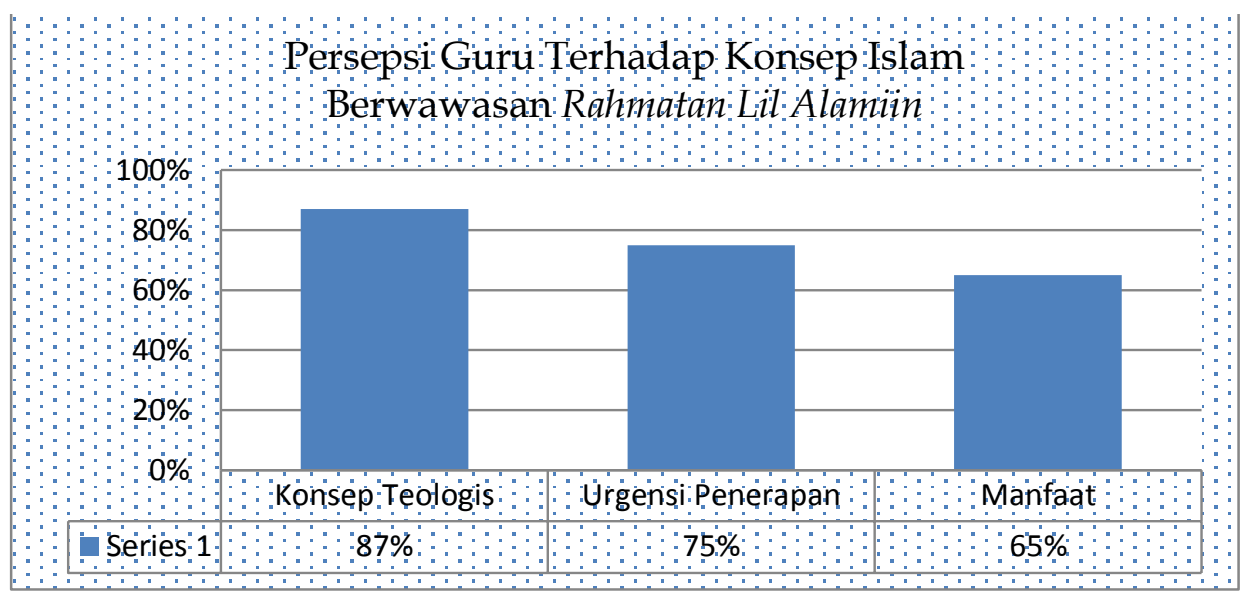

Grafik 1. Persepsi Guru Terhadap Konsep Islam Berwawasan Rahmatan Lil Alamiin

Berdasarkan grafik 1 dimaksud bahwa hasil survey persepsi guru sekolah umum di Jawa Barat terhadap konsep Islam Berwawasan Rahmatan Lil Alamiin diperoleh data bahwa 87 \% guru memiliki pandangan keislaman yang sejalan dengan konsepsi Islam Rahmatan Lil Alamiin, 75 \% guru memandang pentingnya konsep Islam Rahmatan Lil Alamiin diterapkan bagi pelajar beragama Islam, selanjutnya terdapat $65 \%$ guru berpandangan bahwa penerapan konsep tersebut memiliki manfaat berarti bagi pelajar.

Berpijak terhadap hasil survey tersebut dapat disimpulkan bahwa mayoritas guru memiliki persepsi yang baik terhadap konsepsi Islam konsep Islam berwawasan Rahmatan Lil Alamiin bahkan guru memandang konsepsi keislaman dimaksud sangat penting diterapkan dalam proses layanan pendidikan di sekolah umum.

Sementara alasan guru memandang penting menerapkan konsep Islam berwawasan Rahmatan Lil Alamiin dilihat dari 3 aspek yaitu ketepatan konsep sesuai dengan hakikat ajaran Islam, relevansi dengan tujuan agama dan dapat berfungsi untuk pencegahan dari kerentanan anak terpapar faham menyimpang. Adapun hasil survey terkait alasan guru sebagai berikut: 


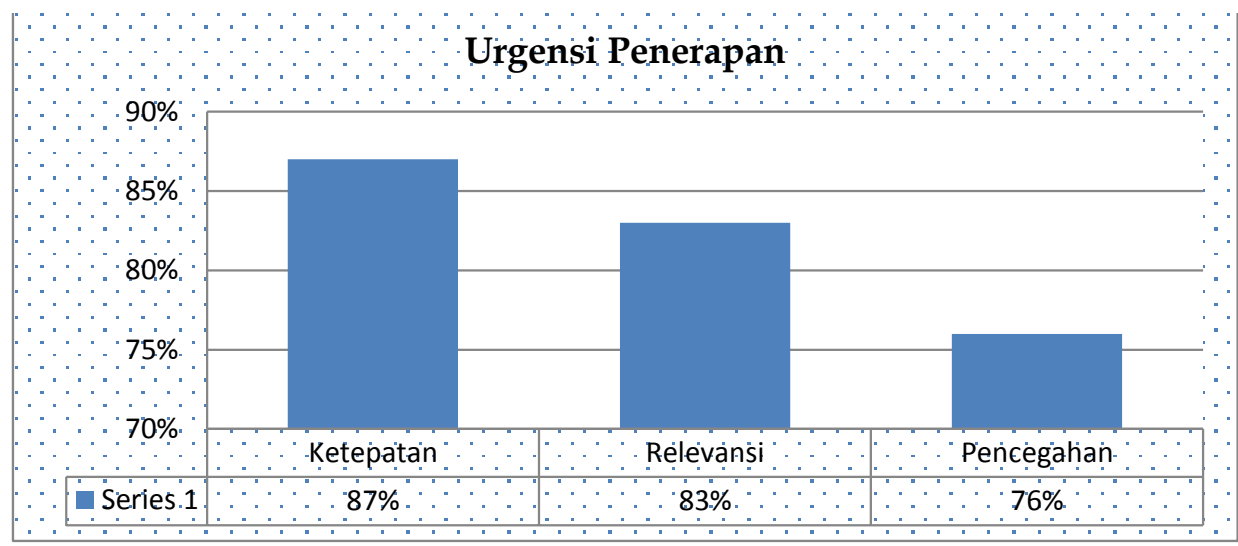

Grafik 2. Urgensi Penerapan Konsep Islam Berwawasan Rahmatan Lil Alamiin

Berdasarkan grafik 2, terpotret bahwa alasan guru memandang penting penerapan Konsep Islam Berwawasan Rahmatan Lil Alamiin diperoleh data, $87 \%$ guru beralasan karena konsep tersebut tepat sesuai dengan hakikat ajaran Islam, selanjutnya 83\% guru berpandangan karena relevan dengan hakikat tujuan agama serta $76 \%$ beralasan karena dengan diterapkannya konsep Islam Berwawasan Rahmatan Lil Alamiin dalam pembelajaran bagi pelajar beragama Islam memiliki manfaat untuk pencegahan dari kerentanan anak terpapar faham menyimpang.

Hasil survey tersebut meneguhkan sikap mayoritas guru sekolah umum di Jawa Barat akan pentingnya penerapan pembelajaran keislaman yang berwawasan rahmatan lil 'alamiin. Secara umum dengan melihat tingginya persentase alasa guru baik alasan ketepatan, relevansi dan manfaat untuk pencegahan dapat dipaandang sebagai komitmen besar guru dalam memahami Islam secara kompehensif dan komitmennya untuk mencegahan pemahaman keislaman yang menyimpang. Karena kesalahan apalagi penyimpangan memahami ajaran Islam dapat berdampak pada pelajar.

\section{Dampaknya Terhadap Sikap Nasionalisme Pelajar di Sekolah Umum}

Menurut Kamus Besar Bahasa Indonesia menyatakan bahwa nasionalisme adalah paham (ajaran) untuk mencintai bangsa dan negara sendiri atau kesadaran keanggotaan dalam suatu bangsa yang secara potensial atau aktual bersama-sama mencapai, mempertahankan dan mengabdikan identitas, integritas, kemakmuran, dan kekuatan bangsa itu semangat kebangsaan. ${ }^{23}$

\footnotetext{
${ }^{23}$ Kamus Besar Bahasa Indonesia, Jakarta:Balai Pustaka, 2007 hal 775-776
} 
Dalam survey ini, yang dimaksud nasionalisme terdapat 7 (tujuh) indikator meliputi; bangga sebagai bangsa Indonesia, cinta tanah air dan bangsa, menerima dan menghargai kemajemukan, bangga pada budaya yang beraneka ragam, menghargaai jasa para pahlawan dan mengutamakan kepentingan bangsa. Adapun hasil survey diperoleh data sebagai berikut:

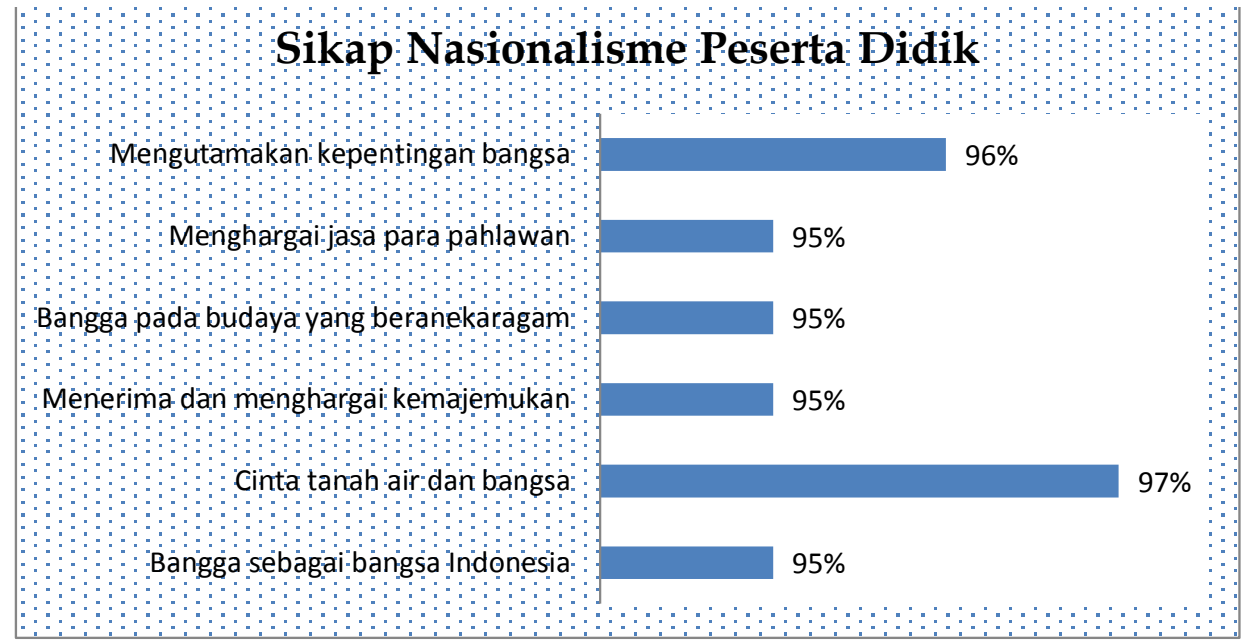

Grafik 3. Dampak Persepsi Guru Tentang Konsep Islam Berwawasan Rahmatan Lil Alamiin Terhadap Sikap Nasionalisme Pelajar

Berdasarkan grafik 3 dimaksud diperoleh data bahwa sikap nasionalisme pelajar di sekolah umum di Jawa Barat, 95\% pelajar bangga sebagai bangsa Indonesia, $97 \%$ pelajar menyatakan cinta tanah air dan bangsa, 95\% pelajar berkomitmen menerima dan menghargai kemajemukan, sementara $95 \%$ pelajar bangga pada budaya yang beraneka ragam, 95\% pelajar, menghormati jasa para pahlawan serta $96 \%$ pelajar memiliki sikap mengutamakan kepentingan bangsa.

Menurut Sarlito W. Sarwono, ${ }^{24}$ sikap terbentuk melalui 4 faktor yaitu pertama, adopsi; kejadian-kejadian dan peristiwa-peristiwa yang terjadi secara berulang dan terus-menerus secara bertahap diserap ke dalam diri individu dan mepengaruhi terbentuknya suatu sikap seseorang. Dalam hal ini, proses belajar di sekolah merupakan juga bagian dari proses adopsi. Kedua, diferensiasi; dengan berkembangnya inteligensi, bertambahnya pengalaman, sejalan dengan bertambahnya usia, konsekuensinya ada halhal yang awalnya dianggap sejenis, selanjutnya dipandang tersendiri lepas dari jenisnya. Ketiga, integrasi: pembentukan sikap terjadi secara bertahap,

${ }^{24}$ Sarlito W.Sarwono, Pengantar Psikologi Umum (Jakarta: Rajawali Pers, 2013), 201.

Kodifikasia: Jurnal Penelitian Islam, Volume, 15 No. 1 Tahun 2021 
dimulai dengan berbagai pengalaman terkait satu hal tertentu, akhirnya terbentuk sikap. Keempat, trauma: trauma merupakan pengalaman yang tiba-tiba, mengejutkan dan meninggalkan kesan mendalam pada jiwa seseorang.

Dengan demikian, persepsi guru terhadap suatu hal termasuk persepsi terhadap konsep Islam rahmatan lil alamiin, secara perlahan akan diadopsi membentuk sikap pelajar dan dapat menjadi pengalaman pelajar dalam memandang konsepsi ajaran Islam. Jika guru memiliki pandangan yang komprehensif terhadap ajaran Islam, maka secara kausalitas akan mempengaruhi proses pembentukan sikap anak baik pada aspek religiusitas maupun sikap nasionalismenya.

\section{PENUTUP}

Guru merupakan salah satu faktor kunci dalam pembentukan pembentukan sikap pelajar. Corak pemahaman keislaman yang dimiliki guru, umumnya tidak hanya diekspresikan dalam praktik teologis, namun mempengaruhi sikap dirinya dalam berbangsa dan bernegara serta proses transmisi kepada pelajar.

Dalam penelitian ini persepsi guru terhadap konsepsi Islam berwawasan rahmatan lil alamiin dilihat dari tiga aspek yaitu persepsi terhadap konsep teologis, urgensi penerapan dan manfaat. Adapun sikap nasionalisme pelajar dilihat dari tujuh indikator meliputi; bangga sebagai bangsa Indonesia, cinta tanah air dan bangsa, menerima dan menghargai kemajemukan, bangga pada budaya yang beraneka ragam, menghargaai jasa para pahlawan dan mengutamakan kepentingan bangsa.

Hasil penelitian ini ditemukan bahwa mayoritas guru memiliki pandangan positif terhadap konsepsi Islam berwawasan rahmatan lil alamiin dan berdampak terhadap sikap nasionalisme pelajar. Pendek kata, secara umum guru memiliki pandangan moderasi beragama secara baik. Hal ini mengkonfirmasi sejumlah studi yang menyatakan bahwa corak keagamaan guru akan mempengaruhi sikap kebangsaannya dan sikap kebangsaan guru akan mempengaruhi pembentukan nasionalisme peserta didik.

Oleh karena itu, seiring dengan ancaman internasionalisasi nilai-nilai negara lain melalui dunia siber, penguatan nasionalisme peserta didik sangat mendesak. Konsekuensinya, berbagai terobosan pendekatan perlu dikembangkan agar nasionalisme peserta didik dapat tumbuh dan terawat secara kokoh. Moderasi beragama melalui konsep Islam berwawasan rahmatan lil alamiin dapat menjadi salah satu terobosan solutif untuk untuk penguatan nasionalisme peserta didik di Indonesia. 


\section{DAFTAR RUJUKAN}

Asy'arie, Musa. Filsafat Islam Tentang Kebudayaan. Yogyakarta: LEFSI, 1999. Imron, Ali. Membangun Islam Nusantara. Jakarta: Pusat Kajian Islam Nusantara, 2019.

Iqbal, Muhammad. The Reconstruction of Religious Thought in Islam. Lahore: Asyraf Publication, 1971.

Jamaludin. Islam Dan Masa Depan Covil Society. Depok: Mutiara Press, 2019.

—. Kepemimpinan Pendidikan. Depok: Mutiara Press, 2020.

Kurzman, Charles. Islam Liberal. Jakarta: Paramadina, 2003.

Manaf, Firman. Agama Dan Integrasi Sosial. Jakarta: Wacana Press, 2018.

Maritain, Jaquet. Integral Humanism: Temporal And Spiritual Problem of a New Christen Don. USA: University of Rorte Dome, 1973.

Maufur. "ISLAM SEBAGAI RAHMATAN LIL-ALAMIN." Kawistara 2, no. 1 (2012): 97-100.

Messakh, Jeni. "Wujud Akulturasi Sebagai Pembentuk Identitas Arsitektur Nusa Tenggara Timur." E-Journal Graduate Unpar 1, no. 2 (September 29, 2014): 178-88. https://journal.unpar.ac.id/index.php/unpargraduate/ article/view/1196.

Miftah, Muhammad. Komunikasi Pendidikan Yang Ramah Anak. Jakarta: Inisiasi Press, 2018.

Moleong, Lexy J. Metodologi Penelitian Kualitatif. Bandung: PT Remaja Rosdakarya, 2002.

Paul Johnson, Doyle. Teori Sosiologi Klasik Dan Modern. Jakarta: Gramedia, 1988.

Purnomo, Hadi, and Umiarso Umiarso. "Pengelolaan Dan Sistem Pendidikan Islam Berwawasan Rahmatan Lil'alamin: Kajian Atas Gerakan Pendidikan Fethullah Gulen Movement." Cendekia: Jurnal Kependidikan Dan Kemasyarakatan 16, no. 2 (November 22, 2018): 223. https://doi.org/10.21154/cendekia.v16i2.1288. 
Rahmatika, Arina, and Ninda Khoirullina. "Upaya Meneguhkan Islam Rahmatan Lil'alamin Melalui Majalah Bangkit." Jurnal Dakwah Dan Komunikasi IAIN 5, no. 2 (2020).

Sobur, Alex. Psikologi Umum. Bandung: Pustaka Setia, 2003.

Soelaeman, M. Munandar. Ilmu Sosial Dasar Teori Dan Konsep Ilmu Sosial. Bandung: ERSCO, 1987.

Solehudin. Menuju Islam Ramah. Jakarta: El-Kahfi, 2009.

Sugiyono. Metode Penelitian Pendidikan (Pendekatan Kuantitatif, Kualitatif, Dan RED). Cet. 25. Bandung: Alfabeta, 2017.

W.Sarwono, Sarlito. Pengantar Psikologi Umum. Jakarta: Rajawali Pers, 2013. 